\title{
The effect of high and low levels of dietary inorganic phosphate on the pre-laying storage of calcium and phosphorus and on the composition of the medullary and cortical bone in pullets
}

\author{
By T. G. TAYLOR AND J. H. MOORE \\ Department of Agricultural Chemistry, University of Reading \\ (Received I6 May 1957)
}

There is considerable evidence that 7-10 days before a pullet begins to lay a new system of secondary bone is laid down, under the combined influence of androgens and oestrogens, in the marrow cavities of all the bones in the skeleton in which haematopoietic tissue is present (Taylor $\&$ Moore, 1956). This medullary bone forms a highly labile reserve of minerals which are mobilized during the calcification of the egg-shell. During the immediate pre-laying period, greatly increased amounts of calcium and phosphorus are retained from the food for the calcification of the medullary bone. Common (1933, 1936, 1938) found that with a high-Ca ration (approximately $2.0 \%$ $\mathrm{Ca}$ ) the $\mathrm{Ca}: \mathrm{P}$ ratio of the retained minerals was often far higher than that of normal bone, but not when a low-Ca ration (approximately $0.26 \% \mathrm{Ca}$ ) was given. The effect of a high-Ca ration during the pre-laying period was confirmed by Taylor \& Moore (1954).

While the medullary bone is developing the ovary and oviduct show phenomenal growth, the ovary increasing in fresh weight from $\mathrm{r} \cdot 0$ to at least $60.0 \mathrm{~g}$ and the oviduct from $2 \cdot 0-3.0 \mathrm{~g}$ to approximately $70.0 \mathrm{~g}$, and in laying pullets these tissues together contain approximately $0.35 \mathrm{~g}$ more $\mathrm{P}$ than in pullets of the same age and weight which have not entered into reproductive activity (Taylor $\&$ Moore, I955). The Ca:P ratio of the mineral actually available from the food for the calcification of the medullary bone is therefore even higher than the balance figures would suggest, since some of the retained $P$ is required for the developing ovary and oviduct. Nevertheless, the Ca:P ratio of the medullary bone of pullets maintained on a high-Ca ration is within the range for normal bone (Taylor \& Moore, I954) so it is clear that P must be available from elsewhere in the body to counterbalance the $\mathrm{P}$ deficiency in the absorbed minerals. The only sources of additional $P$ for the calcification of the medullary bone are the cortical bone and soft tissues, and these sources have been studied in the present work. At the same time, the hypothesis that the rations on which retention of bone-forming minerals with a very high $\mathrm{Ca}: \mathrm{P}$ ratio occur are deficient in available $\mathrm{P}$, owing to the fact that a large proportion of the $P$ contained in these rations is in the form of phytate, has been tested.

\section{EXPERIMENTAL}

Procedure. Eight Rhode Island Red $\times$ Light Sussex pullets, about 7 months old, were maintained in separate metabolism cages and given a daily ration of $120 \mathrm{~g}$ basal meal to which were added $2 \mathrm{ml}$. cod-liver oil and $6.0 \mathrm{~g}$ precipitated calcium phosphate 
(birds nos. I-4) or $5.5 \mathrm{~g}$ calcium carbonate (birds nos. $5-8$ ). The calcium carbonatesupplemented (low-P) ration provided daily $2.27 \mathrm{~g} \mathrm{Ca}$ and $0.75 \mathrm{~g} \mathrm{P}$ and the phosphatesupplemented (high-P) ration $2 \cdot 26 \mathrm{~g}$ Ca and $\mathrm{r} \cdot 88 \mathrm{~g} \mathrm{P}$. The meal and supplements were made into a crumbly mash with $80 \mathrm{ml}$. of a solution containing $0.5 \%(\mathrm{w} / \mathrm{v})$ $\mathrm{NaCl}$ and $0.0125 \%(\mathrm{w} / \mathrm{v}) \mathrm{MnSO}_{4} \cdot{ }_{4} \mathrm{H}_{2} \mathrm{O}$. The composition of the basal meal in parts by weight was as follows: maize 60 , fine miller's offal 15 , bran ro, extracted soya-bean meal $\mathrm{Io}$ and dried yeast Io. This meal contained $0.074 \% \mathrm{Ca}$ and $0.628 \% \mathrm{P}$. Droppings were collected every 2 days after a preliminary feeding period of $48 \mathrm{~h}$.

The birds were killed immediately after they had laid their first egg and the bones prepared for analysis as described previously (Taylor \& Moore, 1954). Exactly onehalf of each skeleton was ashed in a muffle furnace at $600^{\circ}$ in order to determine the total amount of $\mathrm{Ca}$ and $\mathrm{P}$ present. The skeleton was divided for ashing by taking one of each of the paired bones, alternate vertebrae, half the skull divided by a median incision and half the sternum after coarse grinding. The remaining femur of each bird was separated into cortical and medullary bone by careful scraping, and after they had been ground to pass a $300-$ mesh (B.S.) sieve, both types of bone were purified by carbon-tetrachloride treatment as described in a previous paper (Taylor \& Moore, I956).

The muscle tissue was dissected from the carcasses, minced, dried at $100^{\circ}$ overnight and ground in a laboratory mill. The livers were also dried and ground. Samples of ground liver and muscle were extracted in a Soxhlet apparatus for $24 \mathrm{~h}$ with light petroleum (B.P. $40-60^{\circ}$ ).

Analytical methods. Droppings and bone ash were analysed for $\mathrm{Ca}$ and $\mathrm{P}$ by the methods reported earlier (Taylor \& Moore, 1954). The P content of the fat-extracted muscle and livers, and of the unextracted muscle was determined as for the droppings. The cortical- and medullary-bone tissue from the femora was analysed for $\mathrm{Ca}, \mathrm{P}$, magnesium, sodium, potassium, citrate and carbon dioxide as in previous experiments (Taylor \& Moore, 1956).

RESULTS

Pre-laying storage of minerals. The droppings excreted during the collection period immediately before laying, containing the excreted $\mathrm{P}$ associated with the formation of the first shell (Common, 1932; Tyler \& Willcox, 1942) were discarded and the retention of $\mathrm{Ca}$ and $\mathrm{P}$ from the 8th to the 2nd day before laying was calculated from the 2-day balance figures. The figures are given in Table I together with the $\mathrm{Ca}: \mathrm{P}$ ratios of the retained minerals.

The $\mathrm{Ca}: \mathrm{P}$ ratios of the bone-forming mineral stored by the pullets given additional phosphate were much lower than those for the birds given a supplement of calcium carbonate, although ratios for the latter birds were considerably lower than the ratios reported previously for pullets fed on a similar ration (Common, 1936; Taylor \& Moore, 1954). The mean weight of $\mathrm{Ca}$ stored by the birds given calcium phosphate was $0.45 \mathrm{~g}$ more than for the birds given calcium carbonate and the mean weight of $P$ stored was $0.67 \mathrm{~g}$ more.

The $\mathrm{Ca}$ and $\mathrm{P}$ content of the whole skeleton. The dry fat-free weights of the skeletons 
Table I. Retention of calcium and phosphorus during the pre-laying period by the experimental pullets, weights of phosphorus calculated to have been stored in the medullary bone* and excess or deficit of retained P† after providing for medullary bone $P$

\begin{tabular}{|c|c|c|c|c|c|c|c|}
\hline Treatment & $\begin{array}{l}\text { Bird } \\
\text { no. }\end{array}$ & $\begin{array}{l}\text { Ca retained } \\
\text { from food } \\
\text { (g) }\end{array}$ & $\begin{array}{c}\text { Ca:P ratio } \\
\text { of medullary } \\
\text { bone }\end{array}$ & $\begin{array}{l}P \text { stored in } \\
\text { medullary } \\
\text { bone } \\
\text { (g) }\end{array}$ & $\begin{array}{l}\text { P retained } \\
\text { from food } \\
\text { (g) }\end{array}$ & $\begin{array}{l}\text { P excess } \\
\text { or deficit } \\
(\mathrm{g})\end{array}$ & $\begin{array}{c}\text { Ca: } P \text { ratio of } \\
\text { bone-forming } \\
\text { mineral } \\
\text { retained }\end{array}$ \\
\hline \multirow{5}{*}{$\begin{array}{l}\text { High-phosphate } \\
\text { diet }\end{array}$} & I & $2 \cdot 90$ & $2 \cdot 20$ & $1 \cdot 32$ & I'79 & +0.47 & $I \cdot 6 I$ \\
\hline & 2 & $2 \cdot 14$ & $2 \cdot 19$ & 0.98 & $1 \cdot 45$ & +0.47 & $1 \cdot 47$ \\
\hline & 3 & 4.18 & $2 \cdot 17$ & $I \cdot 93$ & $2 \cdot 07$ & +0.14 & 2.02 \\
\hline & 4 & $2 \cdot 86$ & $2 \cdot 21$ & $I \cdot 30$ & I.85 & +0.55 & $\mathrm{I} \cdot 55$ \\
\hline & Mean & 3.02 & $2 \cdot 19$ & $1 \cdot 38$ & I'79 & +0.41 & $I \cdot 66$ \\
\hline \multirow{5}{*}{$\begin{array}{l}\text { Low-phosphate } \\
\text { diet }\end{array}$} & 5 & 3.53 & $2 \cdot 26$ & $1 \cdot 56$ & I 47 & -0.09 & 2.40 \\
\hline & 6 & $2 \cdot 40$ & $2 \cdot 27$ & $1 \cdot 06$ & $1 \cdot 00$ & -0.06 & $2 \cdot 39$ \\
\hline & 7 & $1 \cdot 47$ & $2 \cdot 28$ & 0.65 & 0.65 & 0.00 & $2 \cdot 26$ \\
\hline & 8 & $2 \cdot 89$ & $2 \cdot 20$ & $I \cdot 3 I$ & $r \cdot 36$ & +0.05 & $2 \cdot 13$ \\
\hline & Mean & 2.57 & $2 \cdot 25$ & $\mathrm{I} \cdot \mathrm{I} 5$ & $I \cdot 12$ & -0.02 & $2 \cdot 30$ \\
\hline
\end{tabular}

* On the assumption that all the Ca retained during this period was stored in the medullary bone and that the Ca:P ratio of this bone was the same as that found when the birds were killed.

$\dagger$ See p. 40 .

Table 2. Weights of dry, fat-free skeletons of the experimental pullets, weights of calcium and phosphorus in the skeletons, and Ca:P ratios of the skeletons

High-phosphate diet

Bird no.

Weight of skeleton (

Weight of $\mathrm{Ca}(\mathrm{g})$

Weight of $P$ (g)

$\mathrm{Ca}: \mathrm{P}$ ratio

No. of days on experimental diet

Live weight at killing (g)

Weight of muscle (dry matter) (g)

Weight of liver (dry matter)

(g)

\begin{tabular}{|c|c|c|c|c|}
\hline \multicolumn{5}{|c|}{ High-phosphate diet } \\
\hline $\mathbf{I}$ & 2 & 3 & 4 & Mean \\
\hline $86 \cdot 8$ & $94^{\prime I}$ & 107.0 & I 10.8 & - \\
\hline I $8 \cdot 8 \mathrm{I}$ & $2 I \cdot 09$ & $23 \cdot 94$ & $24 \cdot 34$ & - \\
\hline $8 \cdot 75$ & $9 \cdot 80$ & II $\cdot 38$ & $11 \cdot 39$ & - \\
\hline $2 \cdot 15$ & $2 \cdot 15$ & $2 \cdot 10$ & $2 \cdot 14$ & $2 \cdot 14$ \\
\hline 22 & 12 & 28 & 22 & - \\
\hline 54 & 2274 & 2594 & 2439 & 一 \\
\hline 16.0 & $x 66 \cdot 0$ & $244^{\circ} 0$ & $224^{\circ} 0$ & 一 \\
\hline $34 \cdot 2$ & $20 \cdot 6$ & 24.9 & $26 \cdot 8$ & - \\
\hline
\end{tabular}

Bird no.

Weight of skeleton (g)

Weight of $\mathrm{Ca}(\mathrm{g})$

Weight of $P(g)$

$\mathrm{Ca}: \mathrm{P}$ ratio

No. of days on experimental

$34 \cdot 2$

Low-phosphate diet

diet

Live weight at killing (g) 2597

Weight of muscle (dry matter) $222{ }^{\circ} \mathrm{O}$

(g)

Weight of liver (dry matter) $\quad$ I6.6

56

7

$90 \cdot 3$

20.45

9.40

$11 \cdot 70$

$2 \cdot 17$

28

$2 \cdot 17$

18

22

2402

$236 \cdot 0$

$191 \cdot 0$

$23 \cdot 0$

$22 \cdot 0$

$\begin{array}{cc}8 & \text { Mean } \\ \text { I0I.7 } & - \\ 23.40 & - \\ 10.89 & - \\ 2 \cdot 13 & 2 \cdot 16 \\ 26 & - \\ 2624 & - \\ 240.0 & - \\ 24.8 & -\end{array}$

(g)

and the weights of $\mathrm{Ca}$ and $\mathrm{P}$ that each contained are given in Table 2 together with the Ca:P ratios. With the exception of bird no. 8 the $\mathrm{Ca}: \mathrm{P}$ ratios of all the low-P pullets were higher than the ratios of the high-P birds. The skeleton of bird no. 8 


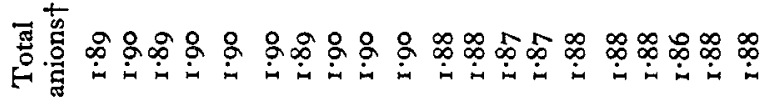

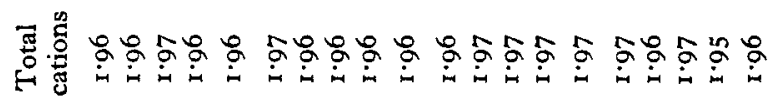

نี

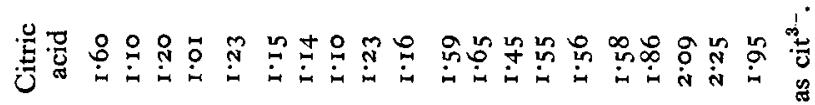

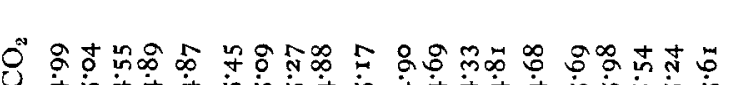

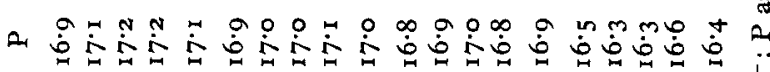

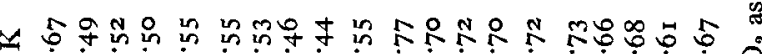

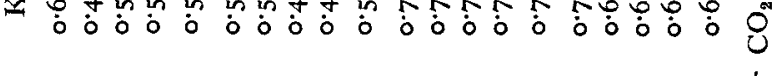

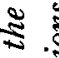

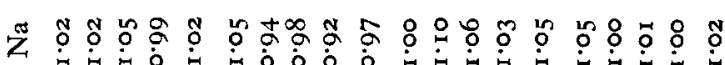

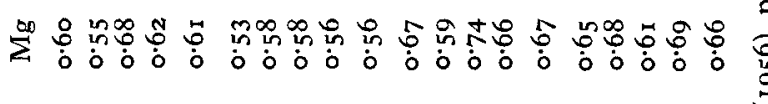

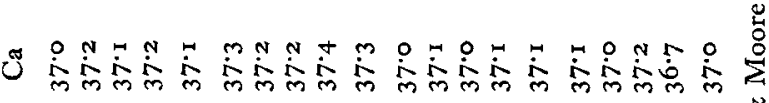

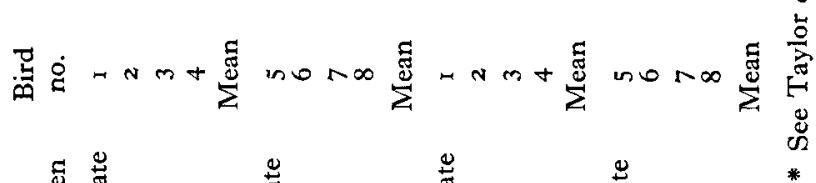

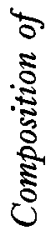

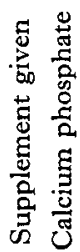

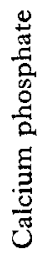

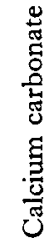

$\stackrel{\stackrel{m}{0}}{\frac{0}{0}}$

蒫

密 
with a $\mathrm{Ca}: \mathrm{P}$ ratio of $2 \cdot 13$ was more similar in composition to that of a high-P bird.

Composition of cortical-and medullary-bone ash. The percentage composition of the ash of the cortical and medullary bone from the femora of the experimental pullets is given in Table 3. Differences in the composition of the cortical bone from the birds on the two treatments were small, but there was a tendency for the bone from the birds given calcium carbonate to be slightly higher in $\mathrm{Ca}$ and carbon dioxide, and slightly lower in $\mathbf{P}$ than the bone from the birds given a supplement of calcium phosphate. These differences are reflected in a somewhat higher mean $\mathrm{Ca}: \mathrm{P}$ ratio for the bone from the low-P pullets.

The most striking difference in the composition of the medullary bone laid down during the two feeding treatments was in the $P$ content. The mean percentage of $P$ in the ash of the medullary bone from the high-P birds was $16 \cdot 9$, compared with a figure of 16.4 for the low-P birds. With the exception of bird no. 8 the Ca content of the medullary-bone ash from all birds showed little variation, ranging from $37 \cdot 0$ to $37^{\cdot 2} \%$. Bird no. 8 , the medullary-bone ash of which contained only $36.7 \% \mathrm{Ca}$, was quite exceptional and it may be seen from Table 2 that the entire skeleton of this bird had an abnormally low $\mathrm{Ca}: \mathrm{P}$ ratio. The $\mathrm{CO}_{2}$ content of the medullary bone from the low-P birds was substantially higher than that from the high-P birds and, in general, the citrate was higher on the former treatment. Once again, bird no. 8 was exceptional. Compared with those of the other three birds on the low-P treatment its medullary bone was abnormally high in citrate and low in $\mathrm{CO}_{2}$, and it is interesting to note that the cortical bone from this bird was atypical in the same respects.

Comparison of the medullary- and cortical-bone samples from the birds on either treatment showed that the medullary bone contained less $\mathrm{P}$ and more $\mathrm{Mg}, \mathrm{K}$ and citrate, whereas no consistent differences in the $\mathrm{Ca}$ and $\mathrm{Na}$ appeared. The medullary bone from the high-P birds contained less $\mathrm{CO}_{2}$ than the cortical, but in the low-P birds the medullary bone was richer in $\mathrm{CO}_{2}$.

Table 4. Percentage of ether extract and ether-soluble phosphorus in liver and muscle of the experimental pullets, and percentage of total phosphorus in ether-extracted liver and muscle and percentage of total phosphorus in unextracted muscle

\begin{tabular}{|c|c|c|c|c|c|c|c|c|}
\hline \multirow[b]{2}{*}{ Treatment } & \multirow[b]{2}{*}{$\begin{array}{c}\text { Bird } \\
\text { no. }\end{array}$} & \multicolumn{3}{|c|}{ Liver } & \multicolumn{4}{|c|}{ Muscle } \\
\hline & & $\begin{array}{l}\text { Ether } \\
\text { extract } \\
(\%)\end{array}$ & $\begin{array}{c}\mathrm{P} \text { in ether- } \\
\text { extracted } \\
\text { tissue } \\
(\%)\end{array}$ & $\begin{array}{c}\text { Ether- } \\
\text { soluble P } \\
(\%)\end{array}$ & $\begin{array}{c}\text { Ether } \\
\text { extract } \\
(\%)\end{array}$ & $\begin{array}{l}\mathrm{P} \text { in ether- } \\
\text { extracted } \\
\text { tissue } \\
(\%)\end{array}$ & $\begin{array}{l}P \text { in un- } \\
\text { extracted } \\
\text { tissue } \\
(\%)\end{array}$ & $\begin{array}{c}\text { Ether- } \\
\text { soluble P } \\
(\%)\end{array}$ \\
\hline \multirow{5}{*}{$\begin{array}{l}\text { High- } \\
\text { phosphate } \\
\text { diet }\end{array}$} & I & $58 \cdot 2$ & $1 \cdot 28$ & 0.074 & $20 \cdot 6$ & 0.89 & 0.73 & 0.029 \\
\hline & 2 & $40 \cdot 0$ & $I \cdot 30$ & 0.082 & $17 \cdot 7$ & 0.89 & 0.77 & 0.027 \\
\hline & 3 & $55^{\circ} 4$ & $I \cdot 40$ & 0.054 & $22 \cdot 4$ & 0.88 & 0.73 & 0.028 \\
\hline & 4 & $53 \cdot 3$ & $I \cdot 43$ & 0.055 & $20 \cdot 2$ & 0.89 & 0.74 & 0.026 \\
\hline & Mean & & $\mathrm{I} \cdot 35$ & 0.066 & & 0.89 & 0.74 & 0.028 \\
\hline \multirow{5}{*}{$\begin{array}{l}\text { Low- } \\
\text { phosphate } \\
\text { diet }\end{array}$} & 5 & $2 I \cdot 5$ & $1 \cdot 18$ & 0.116 & $17 \cdot 0$ & 0.90 & 0.78 & 0.028 \\
\hline & 6 & $5 x \cdot 7$ & $I \cdot 43$ & 0.083 & $21 \cdot 4$ & 0.91 & 0.75 & 0.027 \\
\hline & 7 & $44^{\circ} \circ$ & $I * 46$ & 0.062 & 19.9 & 0.94 & 0.79 & 0.027 \\
\hline & 8 & 53.2 & 1.50 & 0.079 & $21 \cdot 4$ & 0.87 & 0.73 & 0.029 \\
\hline & Mean & & I. 39 & 0.085 & & 0.90 & 0.76 & 0.028 \\
\hline
\end{tabular}


Also shown in Table 3 is the composition of the sixteen bone samples in terms of equivalents of total cations and anions per $100 \mathrm{~g}$ ash and these values are seen to be very constant in spite of the differences in the composition of the bone samples.

$P$ and fat content of liver and muscle tissues. The percentage of $P$ in the fat-extracted muscle and liver and in the unextracted muscle and the percentage of ether extract and of ether-soluble $\mathrm{P}$ in these tissues are shown in Table 4 . No treatment differences are apparent.

$\mathrm{C} a$ and $P$ stored in medullary bone. If it is assumed that all the $\mathrm{Ca}$ retained by the pullets during the pre-laying period is stored in the medullary bone, then the amount of medullary $P$ may be calculated, since the $\mathrm{Ca}: \mathrm{P}$ ratios of the medullary bone were determined (Table 2). The weights of $P$ retained by the eight pullets during the pre-laying period are known from the balance figures, and it is interesting to compare these weights with the weights of $P$ calculated to have been stored in the medullary bone. This information is given in Table $\mathrm{I}$, and it will be seen that for the high-P birds the mean excess of $P$ retained over and above that required for the calcification of the medullary bone was $0.4 \mathrm{I} \mathrm{g}$, whereas for the low-P birds there was a mean deficit of $0.02 \mathrm{~g}$.

\section{DISCUSSION}

The most important difference in the two rations given in this experiment was the inorganic $\mathrm{P}$ content. The low-P ration contained $0.60 \% \mathrm{P}$, all of which was derived from cereals, soya-bean meal and yeast, whereas the high-P ration contained $\mathrm{I} \cdot 50 \% \mathrm{P}$, $0.9 \%$ being in the form of inorganic $P$ derived from the calcium-phosphate supplement. The former ration was similar to those on which previous workers (Common, 1936; Taylor \& Moore, 1954) had found that pullets retained mineral for bone formation with a very high $\mathrm{Ca}: \mathrm{P}$ ratio during the pre-laying period, but in the present experiment the $\mathrm{Ca}: \mathrm{P}$ ratios of the mineral retained on this ration were only slightly higher than the ratio for normal bone. The $\mathrm{Ca}: \mathrm{P}$ ratio of the bone-forming mineral retained by bird no. 8 was indeed the same as the ratio for the whole skeleton at slaughter and less than the ratio for the medullary bone but, as noted previously, this bird was abnormal in several respects. Three of the four pullets on the high- $\mathrm{P}$ ration retained mineral with a $\mathrm{Ca}: \mathrm{P}$ ratio far lower than that of normal bone and the fourth bird (no. 3) stored mineral with a ratio of $2 \cdot 02$.

It is clear that it is only on rations high in $\mathrm{Ca}$ and low in available $\mathrm{P}$ that pullets retain during the pre-laying period bone-forming mineral with a $\mathrm{Ca}: \mathrm{P}$ ratio greater than that of normal bone. The very high ratios obtained by Common (1936) (3.86 and 4.06 for two pullets on a high-Ca, low-P ration) were for a period 3 weeks before laying and are not, therefore, strictly comparable with the figures obtained in the present experiment, when the period beginning 8 days before the onset of lay was considered, i.e. the period during which medullary-bone formation was proceeding rapidly. The very high ratios found by Taylor \& Moore (1954) can be at least partly explained by the fact that the droppings containing the excretory $\mathrm{P}$ associated with the calcification of the first egg-shell were included in the pre-laying balance.

A problem still remains, however, of establishing the source of the $\mathrm{P}$ required by 
the developing ovary and oviduct, even when the $\mathrm{Ca}: \mathrm{P}$ ratio of the bone mineral stored during the immediate pre-laying period is about the same as the ratio for the medullary bone laid down during this time. With the high-P birds the mean weight of $P$ stored in excess of that accounted for by the medullary bone was $0.4 \mathrm{I} \mathrm{g}$, the approximate amount contained in the fully developed ovary and oviduct together (Taylor \& Moore, 1955), but with the low-P birds no $\mathrm{P}$ was available for these tissues.

In a previous paper (Taylor \& Moore, I954) it was suggested that $\mathrm{P}$ might be released from the soft tissues during the pre-laying period, but in view of the fact that the liver and muscle tissue of the birds on both treatments contained very similar amounts of $P$ this does not seem probable, although the other soft tissues may have behaved differently from the liver and muscle, which together accounted for more than $50 \%$ of the non-fatty soft tissues. A more likely source of $P$ is the cortical bone. In a preliminary experiment (Taylor \& Moore, 1955 ) it was found that the mean $\mathrm{Ca}: \mathrm{P}$ ratio of the cortical bone of pullets maintained on a ration similar to the low-P ration used in the present experiment increased from $2 \cdot 14$ to $2 \cdot 19$ during the pre-laying period. For a bird containing $22.0 \mathrm{~g} \mathrm{Ca}$ in its cortical skeleton a change in $\mathrm{Ca}: \mathrm{P}$ ratio of this magnitude would result in the release of $0.25 \mathrm{~g} \mathrm{P}$, which would make a substantial contribution to the $P$ required by the developing ovary and oviduct. In the present experiment birds were not killed before the onset of reproductive activity, but it would seem reasonable to assume that an increase of a similar magnitude in the $\mathrm{Ca}: \mathrm{P}$ ratio of the cortical bone of the low-P birds occurred. It is probable that the $\mathrm{Ca}: \mathrm{P}$ ratio of the cortical bone of the high-P birds also increased during the prelaying period, but that the increase was less than in the low-P birds, since the mean $\mathrm{Ca}: \mathrm{P}$ ratios of the entire skeletons and of the femora of the high-P pullets were 0.02 units lower than the corresponding ratios for the low-P birds. Perhaps the most likely explanation is that some of the $\mathrm{P}$ is provided by the cortical bone and some by the soft tissues, but further work is required before any definite conclusion can be reached.

There can be little doubt that the low-P ration, in which the greater part of the $\mathrm{P}$ was organically combined, was deficient in available $P$. The birds on this treatment were unable to retain sufficient $P$ for the deposition of the medullary bone and for the developing ovaries and oviducts, and the medullary bone laid down contained less $P$ than in the birds fed on the high-P ration. Common (1940) has shown that cereal phytate is hydrolysed to only a limited extent by hens fed on a diet similar to the low-P diet used in the present work and Moore \& Tyler (1955) made a similar observation on pigs.

Recent work with laying hens in this Department (Jenkins, 1956) has shown that, although rations similar to the high-P and low-P rations used in this experiment supported equally good egg production for the first 6 months of a pullet's productive life, the high-P diet was far superior during the subsequent 3 months, once again emphasizing that a laying ration composed entirely of plant products and without any supplementary inorganic $P$ is deficient in available $P$.

In view of the considerable differences between the phosphate, citrate and $\mathrm{CO}_{2}$ contents of the different bones, the constancy of the total anionic content of the samples is interesting and supports the suggestion made previously (Taylor \& Moore, 1956) 
that variations in the composition of bone minerals are mainly due to variations in the amounts of the different ions adsorbed on the bone crystals. It is visualized that the anion-adsorbing centres of the apatite lattice (the surface $\mathrm{Ca}^{2+}$ ions) are capable of accepting phosphate, carbonate (or bicarbonate) or citrate ions and that the amounts of these different ions actually adsorbed are largely dependent on their relative concentration in the plasma. Thus, in the present experiment, it is suggested that the $\mathrm{P}: \mathrm{CO}_{2}$ and $\mathrm{P}$ : citrate ratios in the blood plasma of the birds given calcium phosphate were higher and the $\mathrm{CO}_{2}$ : citrate ratio lower than in those given a supplement of calcium carbonate and that these differences were reflected in the bone, particularly in the medullary bone with its good vascular supply and intense metabolism.

\section{SUMMARY}

I. The effect of high and low levels of dietary inorganic phosphorus on the prelaying storage of calcium and phosphorus by pullets has been studied by a balance technique. Rations supplemented with either calcium carbonate or calcium phosphate but supplying the same amount of $\mathrm{Ca}$ were fed to two groups of four pullets for a minimum of 12 days immediately before laying. The birds were killed immediately after laying their first egg and the skeletons and soft tissues analysed.

2. The mean $\mathrm{Ca}: \mathrm{P}$ ratios of the mineral stored were $\mathrm{x} \cdot 66$ and $2 \cdot 30$ for the high- and low-P birds, respectively.

3. Calculations showed that, whereas the high-P birds stored sufficient $\mathbf{P}$ for the calcification of the medullary bone and for the developing ovary and oviduct, the low-P birds were unable to retain sufficient $P$ from the food for medullary-bone formation and for the developing reproductive organs.

4. There were no consistent differences in the $P$ content of the liver and muscle tissues of the birds on the two treatments.

5. It is suggested that the cortical bone and the soft tissues other than the liver and muscle made good the $\mathrm{P}$ deficiency.

6. Differences in the cortical bone due to treatment were small, but the medullary bone from the phosphate-supplemented birds was higher in $\mathrm{P}$ and lower in $\mathrm{CO}_{2}$ and citrate than that from the carbonate-supplemented birds.

7. The mean $\mathrm{Ca}: \mathrm{P}$ ratios of the entire skeletons of the high- and low-P pullets were $2 \cdot 14$ and $2 \cdot 16$, respectively.

8. It is apparent that the low-P diet, in which all the $\mathrm{P}$ was derived from plant products, was deficient in available $P$.

\section{REFERENCES}

Common, R. H. (1932). F. agric. Sci. 22, 576.

Common, R. H. (1933). F. agric. Sci. 23, 555.

Common, R. H. (1936). F. agric. Sci. 26, 85 .

Common, R. H. (1938). F. agric. Sci. 28, 347.

Common, R. H. (1940). F. agric. Sci. 30, i13.

Jenkins, N. K. (1956). Private communication.

Moore, J. H. \& Tyler, C. (1955). Brit. F. Nutr. 9, 8I.

Taylor, T. G. \& Moore, J. H. (1954). Brit. F. Nutr. 8, I 12.

Taylor, T. G. \& Moore, J. H. (r955). Unpublished observations.

Taylor, T. G. \& Moore, J. H. (1956). Brit. F. Nutr. 10, $25^{\circ}$.

Tyler, C. \& Willcox, J. S. (1942). F. agric. Sci. 32, 43. 